\title{
CHALLENGES IN HIGHER AGRICULTURAL EDUCATION IN BANGLADESH ${ }^{1}$
}

\author{
M. A. Kashem* \\ Department of Agricultural Extension Education, Bangladesh Agricultural University \\ MYmensingh-2202, Bangladesh
}

\begin{abstract}
The economy of Bangladesh is mainly dependent on agriculture; agricultural development in the country to a great extent is dependent on the contribution of quality agricultural graduates. Agricultural universities on Bangladesh are responsible for producing competent agricultural graduates to cater the needs of the farmers and help them to solve the problems towards higher agricultural production. The existing course curricula and syllabi of the agricultural universities, in many cases, cannot meet the demand of the farmers, especially in the case of crisis situation like salinity, drought, disaster, climatic change etc. In the present article the challenges in higher agricultural education in Bangladesh has been critically reviewed. The present status of higher agricultural education, and challenges in higher agricultural education on different aspects have been discussed. The challenges need to be addressed if the quality agricultural graduates have to be produced by the agricultural universities.
\end{abstract}

Key Words: Challenges, Agricultural, Education, Bangladesh

\section{INTRODUCTION}

Education is the process of bringing desirable change into the behaviour of human beings (Singh 1994). Kashem (2004), however, opined that education in any form is the production of desirable changes in human behaviour as a result of his or her knowledge, experience and the like. The changes in human behaviour among people may take in three forms:

1. Knowledge development (Cognitive domain)

2. Attitude development (Affective domain)

3. Skill development (Psychomotor domain)

The Agricultural Knowledge and Information Systems (AKIS) link people and institutions to promote mutual learning and generate, share and utilize agriculture-related technology, knowledge and information. The system integrates agricultural education, farmers, researchers and extensionists to harness knowledge and information from various sources

\footnotetext{
1Paper was presented at the SAARC Regional Expert Meeting on National Agricultural Education Systems held during 28-30 October 2013 at the Sher-e-Bangla Agricultural University, Sher-eBanglanagar, Dhaka-1215

*Professor, Department of Agricultural Extension Education, Bangladesh Agricultural University, Mymensingh-2202, Bangladesh, Corresponding author (Email: kashem1953@gmail.com)
} 
for better farming and improved livelihoods. The integration is diagrammatically depicted in Fig. 1.

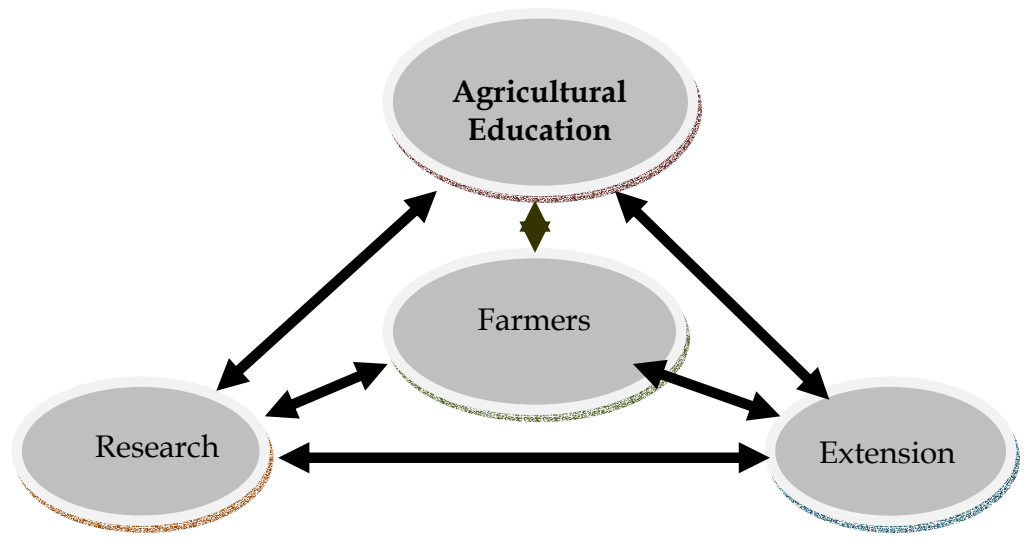

Fig. 1. FAO's AKIS model for knowledge triangle

Rural people, especially farmers, are at the heart of the Knowledge Triangle. Agricultural education, research and extension are services-public or private-designed to respond to their needs for knowledge with which to improve their productivity, incomes and welfare and manage natural resources on which they depend in a sustainable way.

Bangladesh is predominantly an agricultural country where provision of food security, livelihoods improvement and employment generation opportunities of the huge population of the country are directly linked to the development of agriculture. Although Bangladesh is an agro-based country, about $89 \%$ of total farm-holding is below 2.49 acres in size. Farm holdings by size in Bangladesh are presented in Fig. 2.

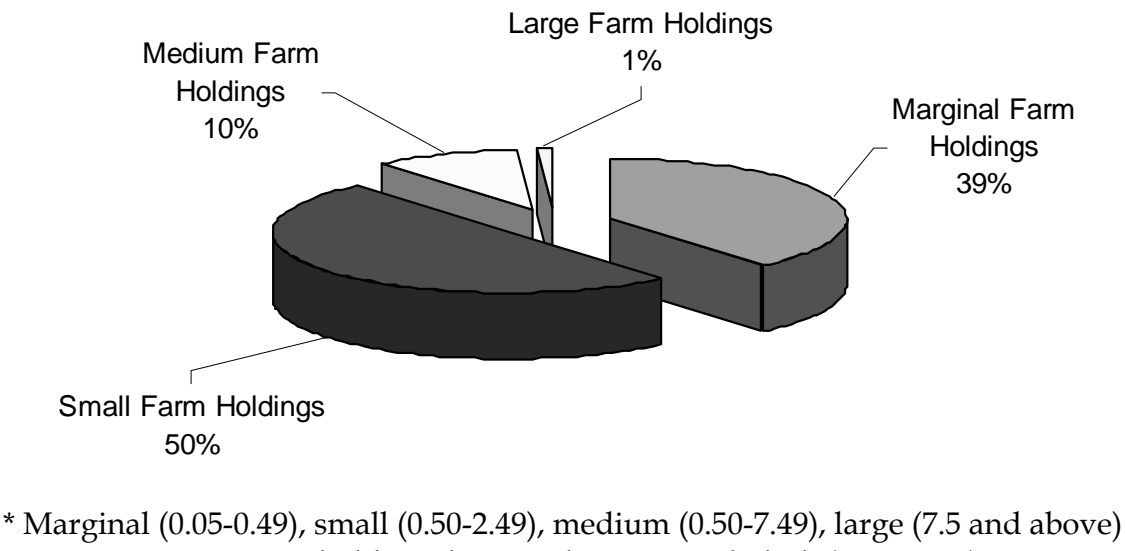

Fig. 2. Farm holdings by size class in Bangladesh (BBS, 2012)

Bangladesh, a country of about 165 million people with a population density of 1250 per square $\mathrm{km}$, is an agricultural country. Almost half of the total population is involved in agricultural activities and more than one-third of the population is economically active in 
agriculture. Agriculture is thus the backbone of the country and is the main driving force for its economy, development and progress. The economic progress of Bangladesh is to a great extent dependent on the development of agriculture. However, due to increased population, declining of per capita cultivable land, adverse effects of climate change, and high price of agricultural inputs the development of agriculture in Bangladesh is now at a great challenge. If the higher agricultural educational institutions have to produce adequate, competent and skilled manpower who would lead the country for its future agricultural development, these will have to face new challenges to cope with new changes in the coming years to provide competent manpower to organizations who are directly involved in agricultural production. The objective of the study, therefore, is to state the present status of higher agricultural education in Bangladesh and highlight the challenges that have to face to bring congenial atmosphere towards achieving the target for quality higher agricultural education at the universities.

\section{Present status of higher agricultural education in Bangladesh}

At present the courses on agricultural education in Bangladesh are being initiated from primary, secondary, agricultural colleges and finally from the universities. Three year diploma courses in agriculture are being offered from the 14 Agricultural Training Institutes (ATIs) administered by the Department of Agricultural Extension (DAE) and more than 140 private ATIs across the country. Four year graduation degrees in agriculture, veterinary science, animal husbandry, fisheries, agricultural engineering, and food engineering and agricultural economics are being offered from the four Agricultural Universities, two Science and Technology Universities, Chittagong Veterinary and Animal Sciences University, Khulna University, Rajshahi University and Dhaka University. The Bangladesh Agricultural University (BAU) is the oldest agricultural university in the country which was established in 1961 in Mymensingh. The course curricula of the BAU has been initially designed in 1961 for 5 year B.Sc.Ag. (Hons.) degree after SSC including two year professional courses; the major changes were made 1970 with the introduction 4 year B.Sc.Ag. (Hons.) degree after HSC. The course curricula of agricultural universities had been designed almost in the light of the BAU. The course curricula of the BAU and agricultural universities including Science and Technology Universities from where agricultural degrees are offered have been modified from time to time on a limited basis but time has come to have major changes in the course curricula in order to produce quality and competent agricultural graduates to meet the future challenges.

\section{Challenges in higher agricultural education in Bangladesh}

There are, in fact, many challenges in higher agricultural education in Bangladesh. However, the most significant and important challenges have been discussed in this paper.

\section{Changing the course curricula to avoid duplication/repetition}

After initial introduction of different courses at the undergraduate and post-graduate levels no major changes have been made at the universities. In a recent study on the alumni of the BAU across the country it was found that most of the alumni are in the opinion that there are considerable duplication/repetition in different subjects. They very specifically mentioned the names of some of the subjects and suggested to replace the issues of 
duplication/repetition by some recently emerging disciplines such as disaster management, biotechnology and genetic engineering, office management, communication skill (oral and written), computer skills, report writing and presentation skills etc.

\section{Modification of course curricula to meet the farmers' needs and aspirations}

The course curricula of the Agricultural Universities and Science and Technology Universities have been prepared quite a long time ago although few changes and modifications have been taken time to time on limited scale. However, during the passage of time lot of changes have occurred in the environment, agro-climatology and natural resources. The present course cannot address all those which are the dire need of the country now, e.g. saline, drought, and flood tolerant technologies. Disaster management: disaster preparedness, mitigation and impact assessment of disasters etc.

\section{Standard students' assessment procedure}

Students' performances are mostly assessed through memorization and understanding, which cannot judge the creativity, ability for application of knowledge gained through teaching, synthesize, compare the ideas learned. Blooms (1956) and Blooms and Anderson (1996) have identified (a) cognitive (knowledge), (b) affective (attitude), and (c) psychomotor (skills) aspects of learning. In cognitive aspect there are six dimensions: (i) remembering, (ii) understanding, (iii) applying, (iv) analyzing, (v) evaluating, and (vi) creating. In affective aspect there are five dimensions: (i) receiving, (ii) responding, (iii) valuing, (iv) organization, and (v) characterization. Finally in psychomotor aspect there are also five dimensions: (i) imitation, (ii) manipulation, (iii) precision,(iv) articulation, and (v) naturalization. During the students' performance assessment so far the first two dimensions of cognitive aspect i.e. remembering and understanding are used in questions for judgment although applied questions are occasionally used to prepare questions. However, in the primary and secondary schools the application of creative questions is in use for a number of years. At the university level, the application of all the dimensions of cognitive, affective and psychomotor are equally needed. However, improvement would not occur spontaneously, it may take time, but we have to start the process immediately. Initially students may face difficulties but with passage of time it would be a normal phenomenon to put the concepts of Blooms and Anderson into practice, which is essentially needed.

\section{Evaluation of teachers' performance}

At present, there is no in-built mechanism to evaluate teachers' performance at the agricultural and other relevant universities. All teachers are equally treated and evaluated during their promotion, nomination for scholarships, training, participation in the conferences, seminar, workshops etc. Consequently no competition among the teachers is observed. Every teacher knows that after passing the required length of service he/she would get his/her promotion; nobody can check it. This really a very disastrous for the universities; without having any efficiency, commitment, skills and devotion to teaching one can get the highest position in the universities. This should not be continued. The university teachers have set and approved charter of duties and responsibilities and work load per week, but only few of them follow this. The per week work load of the teachers of 
the Bangladesh Agricultural university (BAU), Mymensingh are furnished below as ready reference.

Total Work load of the university teachers

\begin{tabular}{c|cc|c|c|c|c|c|c}
\hline Ranks & \multicolumn{2}{|c|}{$\begin{array}{c}\text { Required } \\
\text { teaching class } \\
\text { loads (hours) }\end{array}$} & $\begin{array}{c}\text { Total } \\
\text { (hours) }\end{array}$ & $\begin{array}{c}\text { Seminars \& } \\
\text { research } \\
\text { guidance }\end{array}$ & $\begin{array}{c}\text { Students } \\
\text { counseling }\end{array}$ & $\begin{array}{c}\text { Own } \\
\text { studies \& } \\
\text { research }\end{array}$ & $\begin{array}{c}\text { Administrat } \\
\text { ion \& other } \\
\text { activities }\end{array}$ & $\begin{array}{c}\text { Overall } \\
\text { Total } \\
\text { (hours) }\end{array}$ \\
\cline { 2 - 5 } Lecturer & 06 & 16 & 22 & 02 & 02 & 12 & 02 & 40 \\
$\begin{array}{l}\text { Assistant } \\
\text { Professor }\end{array}$ & 08 & 14 & 22 & 06 & 02 & 08 & 02 & 40 \\
$\begin{array}{l}\text { Associate } \\
\text { Professor }\end{array}$ & 06 & 12 & 18 & 06 & 02 & 10 & 04 & 40 \\
Professor & 04 & 08 & 12 & 08 & 02 & 08 & 10 & 40 \\
\hline
\end{tabular}

Ref. No. 2202(50)/Estt., dated 29 April 1985, Bangladesh Agricultural University, Mymensingh

Remarks:

a) Professor working as Dean may have 06 hrs less from non-teaching assignments; teaching assignments remaining unaffected.

b) Teachers working as Head of Dept., Provost, Proctor, and House Tutor may have 04 hrs less from non-teaching assignment, teaching assignment remaining unaffected.

Ali and Rahman (nd) in their study found that Less than half (45\%) of the senior teachers of BAU possessed good and excellent teaching quality while a quarter of the population (25\%) was very poor in teaching (Table 1).

Table 1. Classification of BAU teachers according to their overall teaching quality

\begin{tabular}{lcc}
\hline \multicolumn{1}{c}{ Classification of teaching quality } & Score range & Percentage of teachers \\
\hline Excellent & $\geq 80$ & 17 \\
Good & $70-79$ & 28 \\
Fair & $60-69$ & 17 \\
Poor & $50-59$ & 13 \\
Very poor & $\leq 49$ & 25 \\
\hline Overall & $27-94$ & 100 \\
\hline
\end{tabular}

There must be an in-built mechanism for teachers' performance evaluation. However, with the initiation of HEQEP (Higher Education Quality Enhancement Project) administered by the UGC and funded by the World Bank 26 projects are now in execution where there is a mechanism for teachers' performance evaluation. In fact after completion of every course, teachers' performance should be evaluated by the respective students. Moreover, peer observation in the class by the senior teachers and performance evaluation in respect of curricular, extra-curricular, students' counseling, commitment to profession, sincerity, punctuality, adjustment to situation etc. of teachers by at least senior teachers of the department should be introduced. The task is of course difficult, but not impossible. 


\section{Unified and standard admission policies in the universities}

At present the public universities have their own admission policies, which differ distinctly from one to another. Some universities take admission tests departmentally. The admission seeking students, sometimes with their family members or relatives, move from university to university for attending admission tests. This is not only the harassment to the students, but it also leads to heavy financial pressure on many poor parents. It is also seen that a meritorious student gets opportunity for admission to several universities and medical college, where many students do not get chance to get admission to any university. After getting admission, it is also seen that a notable segment of the admitted students leave the university to get admitted to other university or medical college, where he/she got selection. The universities usually prepare a long waiting list from where the vacant seats are filled up. This not only leads to financial losses of the university but also creates many administrative hazards. The admission policies at the universities have to be changed and modified. The UGC of Bangladesh should take up the responsibility. However, the UGC alone may not be the sole authority to execute this unless the academicians, especially the Academic Council and Syndicate, of the respective universities do not realize the problems and come forward to solve the problems.

\section{Quality assurance in higher education}

At present, so far known, none of the universities in Bangladesh has Internal Quality Assurance (IQA). But it should be now a mandatory component of each and every university. IQA refers to processes and procedures within the institution to review, evaluate, assess and to ensure the quality of the education provided and/or research undertaken. Similar to the IQA the Internal Quality Monitoring/Audit/Review may also be used.

The purposes of the IQA are:

- Continuous improvement

- Curriculum change and staff development

- Public confidence and information

- External profile

- Encourage the development of quality systems and ensure compliance

- Harmonize workloads

- Consolidate research activity and infrastructure

Considering the importance of IQA, the UGC has already proposed for the establishment of Internal Quality Assurance Cell (IQAC) in each of the public and private universities in Bangladesh in order to take care of the quality assurance of education.

\section{Recognition of degrees by the accreditation council}

Accreditation is an act of granting credit or recognition, especially with respect to educational institution that maintains suitable standards. The purpose of registration of a HEI (Higher Educational Institution) is to certify that an (i) institution is authorized to deliver a higher education courses or degrees and considered to have necessary academic, 
financial, staffing, and physical resource, and (ii) adopts good practices in higher education, committed to uphold high standards \& values and conduct regular internal and external quality assurance.

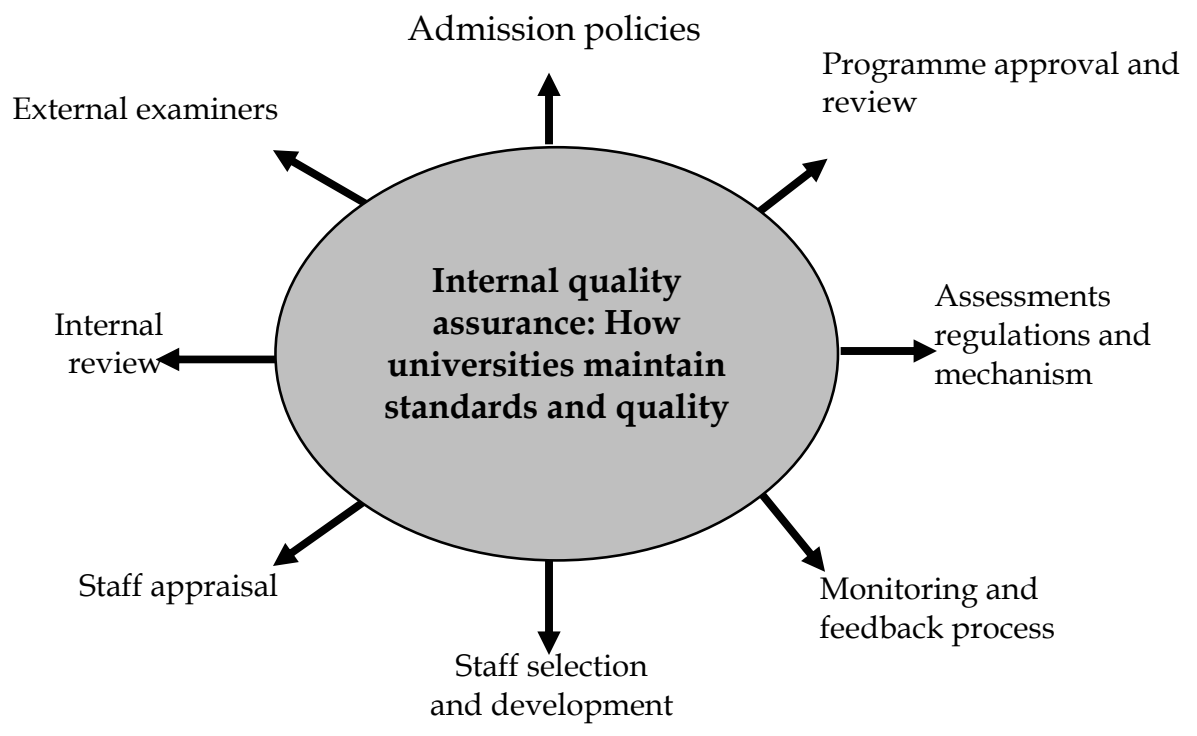

Fig. 2. Functions and responsibilities of internal quality assurance (IQA)

Almost all the countries in world except Bangladesh and only few developing and underdeveloped countries have Accreditation Council of their own, which has approval and recognition of the IARC (International Accreditation and Recognition Council). The UGC of Bangladesh has prepared a draft proposal for establishing National Accreditation Council (NAC), which is now lying with the Ministry of Education for approval. The approval of the degrees offered to the students will be recognized primarily by the National Accreditation Council and finally by the International Accreditation Council. Without recognition of the degrees the passed out graduates would suffer seriously from getting scholarships, employment overseas, consultancies and other facilities that could be their due rights and privileges because of the degrees.

\section{Rethinking of banning teachers' and students' direct involvement in politics}

It is known to everyone that the public universities in Bangladesh are badly affected by the teachers' and students' direct involvement in politics. Recent unrest in some of the public universities is the distinct example of bad effects of students' and teachers' direct affiliation with the national political parties. The political affiliation of the students and teachers very often creates unrest to the universities leading to temporary closure to sine die and even it goes up to fatal cases. It is not at all a congenial atmosphere for the universities for nourishment and overall academic development. However, nobody can deny the importance of leadership development among students through their participation in different academic, cultural and recreational activities. This type of students' leadership 
activities can be exercised through democratic processes i.e. students' representatives for central students' union should be elected non-politically and arrangements and atmosphere needs to create for the selection of best leaders. None can justify the way the students and teachers are involved in political activities now-a-days. There are evidences that some teachers directly use and utilize the students to work in their favour, instead, they provide undue facilities to the students and consequently the academic atmosphere and administration collapse.

\section{CONCLUSION}

The quality of higher agricultural education in Bangladesh is not up to the standard of the advanced as well as other South Asian and South-east Asian developing countries. In almost each and every country has now Accreditation Council at the national level to approve the degrees offered by the universities while the universities have their own Internal Quality Assurance Cell (IQAC) in order to administer, guide, supervise and monitor the various aspects of quality of education. The days are not far when the degrees offered by the Agricultural Universities and other allied universities in Bangladesh will not recognized by the International Accreditation Councils unless Internal Quality Assurance Cell (IQAC) is established at the universities and Central Accreditation Council is formed at the national level.

\section{REFERENCES}

Ali, M. M. and Rahman M. W. nd. Teaching Quality of the Senior Faculty Members of Bangladesh Agricultural University, Mymensingh. (Personal communication).

BBS. 2012. Statistical Yearbook of Bangladesh. Bangladesh Bureau of Statistics. Ministry of Planning, Government of the People's Republic of Bangladesh.

Kashem, M. A. 2004. Fundamentals of Extension Education. Mymensingh: The Lima Printing Press.

Singh, R. 1994. Extension Education. Ludhiana: Sahitya Kala Prokashon. 